doi: $10.15237 /$ gida.GD16098

\title{
EFFECT OF DRYING PROCESS ON PESTICIDE RESIDUES IN GRAPES
}

\author{
Ayşe Özbey ${ }^{1 *}$, Şeyda Karagö $z^{2}$, Ali Cingö $z^{3}$
}
${ }^{1}$ Department of Food Engineering, Faculty of Engineering, Ömer Halisdemir University, Niğde, Turkey
${ }^{2}$ Department of Food Tecnology Zile Vocational High School, Food Technology,
Gaziosmanpaşa University, Zile, Tokat, Turkey
${ }^{3}$ Department of Food Engineering, Faculty of Engineering and Natural Sciences, Gaziosmanpaşa University, Tokat, Turkey

Received / Geliş tarihi: 03.11.2016

Received in revised form / Düzeltilerek Geliș tarihi: 28.11.2016

Accepted / Kabul tarihi: 01.12.2016

\begin{abstract}
In this study, drying kinetics of chlorpyrifos, diazinon, dimethoate and methidathion pesticides on grape samples were determined. Grapes were dried under two conditions: by sunlight (for 21 days) and in a ventilated oven at different temperatures (at $50^{\circ} \mathrm{C}$ for $72 \mathrm{hrs}$, at $60^{\circ} \mathrm{C}$ for $60 \mathrm{hrs}$, at $70{ }^{\circ} \mathrm{C}$ for 48 hrs, at $80^{\circ} \mathrm{C}$ for $36 \mathrm{hrs}$ ). During sun drying, half-lives of chlorpyrifos, diazinon and methidathion were $5.64,6.42$ and 5.25 days, respectively. The data for dimethoate did not fit $0^{\text {th }}, 1^{\text {st }}$ and $2^{\text {nd }}$ order kinetics. During oven-drying, the pesticides followed the first order kinetic model. When the temperature increased, degradation of pesticides raised. The activation energies of dimethoate, diazinon, chlorpyrifos and methidathion were calculated as 42.02, 42.18, 42.01 and $41.08 \mathrm{~J} / \mathrm{mol}$, respectively.
\end{abstract}

Keywords: Grape, oven-drying, pesticides, sun-drying

\section{KURUTMA IŞLEMINIIN ÜZÜMLERDE BULUNAN PESTISITTLER ÜZERINE ETKISI}

\section{Öz}

Bu çalışmada üzümlerde bulunan chlorpyrifos, diazinon, dimethoate ve methidathion pestisitlerinin kurutma kinetikleri belirlenmiştir. Güneşte ve farklı sıcaklılarda $\left(50^{\circ} \mathrm{C}\right.$ 'de 72 saat, $60^{\circ} \mathrm{C}$ 'de 60 saat, $70^{\circ} \mathrm{C}$ 'de 48 saat, $80^{\circ} \mathrm{C}$ 'de 36 saat süre ile) hava akımlı etüvde kurutma işlemi olmak üzere iki farklı kurutma işlemi uygulanmıştır. Güneşte kurutma işleminde chlorpyrifos, diazinon ve methidathion pestisitlerinin yarılanma ömürleri sırasıyla 5.64, 6.42 ve 5.25 gün olarak bulunmuştur. Dimethoate verileri 0., 1. ve 2 . derece kinetik uyumu göstermemiştir. Sıcaklık yükseldikçe pestisitlerin parçalanması artmıştır. Dimethoate, diazinon, chlorpyrifos ve methidathionun aktivasyon enerjileri sirasiyla 42.02, 42.18, 42.01 ve 41.08 $\mathrm{J} / \mathrm{mol}$ olarak hesaplanmıştır.

Anahtar kelimeler: Üzüm, fırında kurutma, pestisit, güneşte kurutma

\footnotetext{
* Yazışmalardan sorumlu yazar / Corresponding author;

4) ayse.ozbey@ohu.edu.tr, (c) (+90) 388225 4305, 岛 (+90) 3882250110
} 


\section{INTRODUCTION}

Grapes are one of the most popular and the widespread cultural fruit in the world. World's fresh grape production is about the 65 million tons per year and the 7.5 million hectares of the world are dedicated to grapes $(1,2)$. Grapes are nutritionally important fruit crops of international trade significance and consumed both as fresh and processed products. The use of pesticides can be beneficial in protecting crops, thereby increasing agriculture production. However multiple applications of a variety of pesticides can lead to residues within the food product (3, 4). Since there is need for pesticide treatments on grapes as near as possible to harvest, high residues could be present on grapes at harvest time (5). Raisins are dehydrated grapes manufactured by exposure to sunlight or oven-drying. It is one of the most important and popular dried fruits in the world because of their high nutrition value (6). The different drying processes have different effects on pesticide residues on raw commodity since sun light may additionally photodegrade pesticide residues (7).

Food processing usually causes a decrease in pesticide levels. However, in some cases, residue levels may increase in the final product due to concentration factors of raw commodities in the process of the final product. This concentration effect can be related with water removal for example in the production of dry fruit such as raisins and prunes. Processing factors assist in the dietary-intake assessment of processed commodities (8). They are also used in recommending MRLs for processed products with an existing Codex commodity code, but only if the processing leads to an increase of the residue level $(7,9,10)$.

The objectives of this work were to determine the effects of sun-drying and oven-drying on chlorpyrifos, diazinon, dimethoate and methidathion residues on grapes.

\section{MATERIAL AND METHODS}

\section{Materials}

The Sultana grape samples were supplied from Manisa (Turkey) in September 2012. Chlorpyrifos (98.5\%), diazinon (99.0\%), dimethoate (98.5\%) and methidathion (98.5\%) standarts were purchased from the Dr. Ehrenstorfer GmbH (Augsburg, Germany).

\section{Apparatus and Chromatography}

Analysis of pesticides was performed using a Perkin Elmer Clarus 500 GC-MS. The separation was conducted on a CP-Sil 8-ms capillary column ( $30 \mathrm{~m}, 0.25 \mathrm{~mm}$ id, $0.25 \mu \mathrm{m}$ film thickness). Helium was used as the carrier gas at the flow rate of 1.3 $\mathrm{mL} \mathrm{min}^{-1}$, and the injection volume was $5.0 \mu \mathrm{L}$. The injection port temperature was held at $250{ }^{\circ} \mathrm{C}$ at the split mode with the split ratio of 1:5. The oven temperature was programmed as follows: $75^{\circ} \mathrm{C}$ held for $3.0 \mathrm{~min}$, and then the temperature was increased to $180{ }^{\circ} \mathrm{C}$ at a rate of $25^{\circ} \mathrm{C} \mathrm{min}-1$ and then the temperature was raised to $300^{\circ} \mathrm{C}$ at a rate of $5^{\circ} \mathrm{C} \mathrm{min}^{-1}$ and maintained for $3 \mathrm{~min}$. Dedector was operated on the EI $(70 \mathrm{eV})$ ionization mode. Scan mode was fullscan ( $40 \mathrm{~m} / \mathrm{z}-360 \mathrm{~m} / \mathrm{z})$, interface temperature and ion source temperature were $250^{\circ} \mathrm{C}$. Processing data was performed using NIST 2008 and Wiley 2002 libraries.

\section{Drying Processes}

To evaluate the effect of drying process on pesticide residues, Sultana grape treated with pesticides (chlorpyrifos $45 \mu \mathrm{L} / \mathrm{kg}$, diazinon $50 \mu \mathrm{L} / \mathrm{kg}$, dimethoate $50 \mu \mathrm{L} / \mathrm{kg}$, methidathion $45 \mu \mathrm{L} / \mathrm{kg}$ ) through spraying onto surface. To maintain the penetration of pesticides, the grapes were kept in a closed container for 12 hours at room temperature. Then grapes were separated from stems and dried. Grapes were dried under two conditions: by sunlight (for 21 days) and in a ventilated oven at different temperatures (at $50^{\circ} \mathrm{C}$ for $72 \mathrm{hrs}$, at 60 ${ }^{\circ} \mathrm{C}$ for $60 \mathrm{hrs}$, at $70{ }^{\circ} \mathrm{C}$ for $48 \mathrm{hrs}$, at $80^{\circ} \mathrm{C}$ for 36 hrs). Moisture content and pesticide analyses were conducted at equal time intervals. Moisture content was determined according to AOAC (11).

\section{Pesticide Analysis}

QuECHERS method (12) was used to extract pesticides residues from grapes. Grape samples were homogenized and $15 \mathrm{~g}$ of each homogenate was weighed into a $50 \mathrm{~mL}$ centrifuge tube. Then $15 \mathrm{~mL}$ MeCN was added into tube. Tubes were capped well and shaken vigorously by hand for 45 s. $6 \mathrm{~g}$ anhydrous $\mathrm{MgSO}_{4}$ and $1.5 \mathrm{~g} \mathrm{NaCl}$ were 
added and shaken. Tubes were centrifuged at $3000 \mathrm{rpm}$ for $1 \mathrm{~min}$. Extracts were decanted into the dispersive-SPE tubes containing $0.3 \mathrm{~g}$ PSA $+1.8 \mathrm{~g}$ anhydrous $\mathrm{MgSO}_{4}$. Tubes were capped well, shaken by hand for $20 \mathrm{~s}$ and centrifuged for $1 \mathrm{~min}$ at $3000 \mathrm{rpm}$. Supernatant were then analysed by GC/MS.

The recoveries were ranged from 88 to $98 \%$. Detection limit was $0.02 \mathrm{mg} / \mathrm{kg}$ for all pesticides.

\section{Drying Kinetics}

Food processing studies often results in transfer factors or food processing factors (PF) of the pesticide residue in the transition from raw agriculture commodity to the processed product. Processing factors are calculated and considered by JMPR (13) as follows:

Processing factors $=\frac{\text { residue level in processed commodity }}{\text { residue level in raw commodity }}(1)$

In order to determine degradation kinetics, the obtained data were evaluated with zero-order, first-order and second-order kinetic models. All pesticides obey first order kinetic model during drying. The experimental data were fitted according to simple first-order rate:

$\frac{\mathrm{C}}{\mathrm{C}_{0}} \mathrm{e}^{\mathrm{kt}}$

In this equation, $\mathrm{C}_{0}$ is the initial concentration of the pesticides, $\mathrm{k}$ is the rate constant. Half-lives $\left(\mathrm{t}_{1 / 2}\right)$ were calculated from the equation:

$\mathrm{t}_{1 / 2}=\ln (2) / \mathrm{k}$

The temperature dependence of rate constants was described by the Arrhenius equation. Activation energy of pesticides during oven drying was calculated according to Arrhenius equation:

$\mathrm{k}=\mathrm{Ae}^{\mathrm{Ea} / \mathrm{RT}}$

$E_{a}$ : Activation energy

R: Gas constant $\left(8.3145 \mathrm{~J} \mathrm{~mol}^{-1} \mathrm{~K}^{-1}\right)$
T: Absolute temperature

A: Frequency factor

Since rate constants were determined at two temperatures, the following formula derived from the Arrhenius equation was used to calculate activation energy.

$\ln \left(\mathrm{k}_{1} / \mathrm{k}_{2}\right)=-\mathrm{E}_{\mathrm{a}} / \mathrm{R}\left(1 / \mathrm{T}_{1}-1 / \mathrm{T}_{2}\right)$

\section{RESULTS AND DISCUSSION}

\section{Sun Drying}

The moisture content of the fruits reduced to $\sim 10-12 \%$. Chlorpyrifos, diazinon, methidathion and dimethoate disappeared 73, 92, 82 and 39\%, respectively. Processing factors of pesticides are given in Table 1. All pesticides decreased during all drying processes. These results supported by previous work (14).

Figure 1 shows the first order kinetic behaviours of chlorpyrifos, diazinon and methidathion during sun-drying. Half-lives of chlorpyrifos, diazinon and methidathion were 5.64, 6.42 and 5.25 days, respectively. The data for dimethoate did not fit zero, first and second order kinetics.

During sun-drying dimethoate decreased by $39 \%$ probably due to not having chromophores in the molecules (15). Chlorpyrifos, diazinon and methidathion reduced considerably because of their chromophores. Table 2 shows the physicalchemical characteristics of pesticides. As seen from the Table 2, hydrolysis and photolysis are the main mechanisms for the decrease during sun drying. We found that diazinon level mostly decreased because it was very sensitive to photodegradation. Chlorpyrifos level was higher than methidation level after drying although chlorpyrifos more sensitive to photodegradation. However chlorpyrifos was least water soluble pesticide and hydrolysis rate was slower than methidation.

Table 1. Processing factors of pesticides

\begin{tabular}{lcccc}
\hline Process & Dimethoate & Diazinon & Chlorpyriphos & Methidathion \\
\hline $80^{\circ} \mathrm{C}$ & 0 & 0 & 0.09 & 0.02 \\
$70^{\circ} \mathrm{C}$ & 0.01 & 0 & 0.04 & 0.06 \\
$60^{\circ} \mathrm{C}$ & 0.03 & 0.01 & 0.12 & 0.13 \\
$50^{\circ} \mathrm{C}$ & 0.64 & 0.02 & 0.22 & 0.35 \\
Sun-drying & 0.60 & 0.08 & 0.26 & 0.18 \\
\hline
\end{tabular}



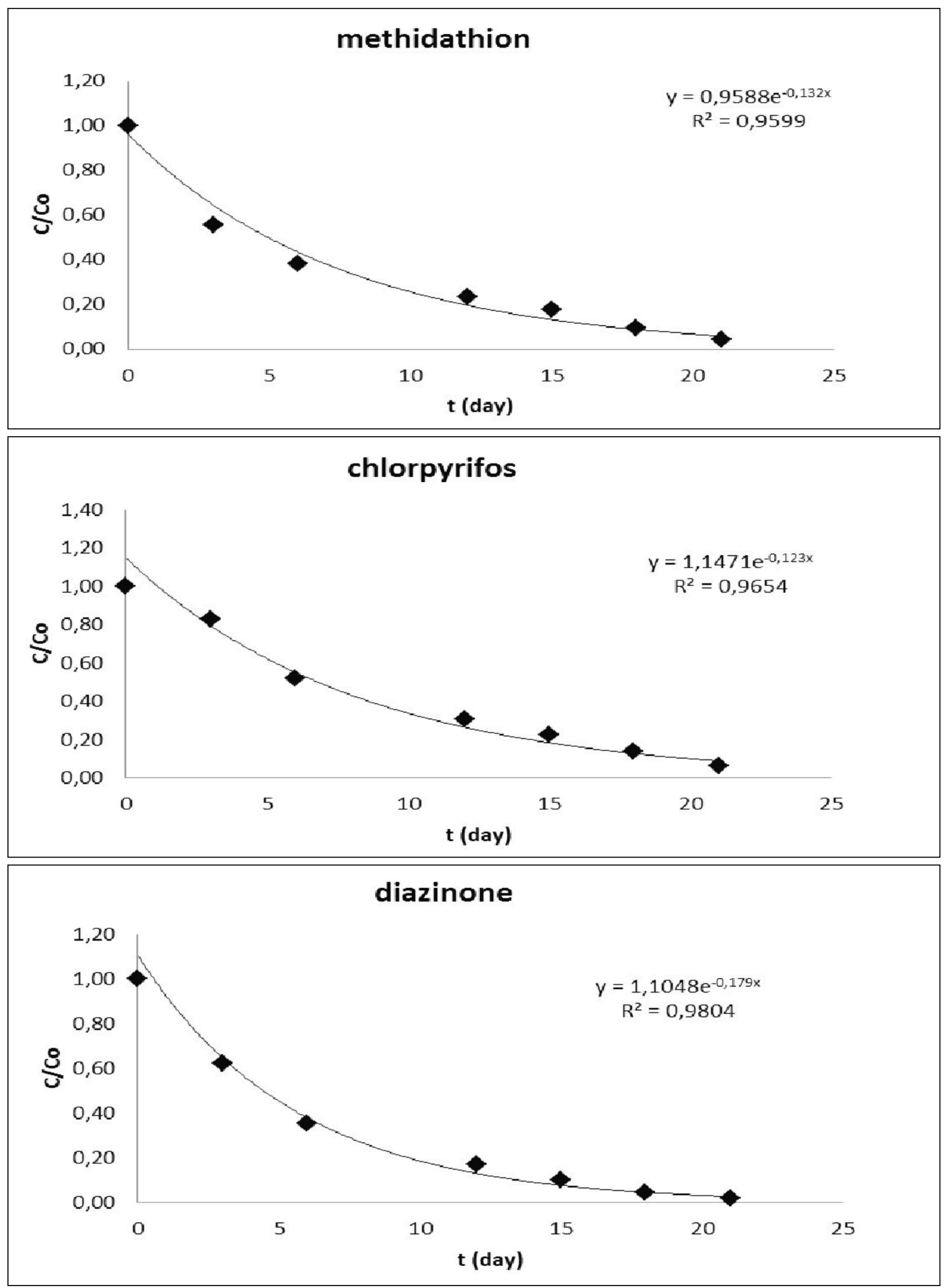

Figure 1. The first order kinetic behaviours of methidathion, chlorpyrifos and diazinon during sun-drying 
Effect of Drying Process on Pesticide Residues in Grapes

Table 2. Physico-chemical properties of pesticides

\begin{tabular}{lcccc}
\hline Parameter & ${ }^{\mathrm{a}}$ Dimethoate & ${ }^{\mathrm{b}}$ Diazinon & ${ }^{\mathrm{c}}$ Chlorpyriphos & ${ }^{\mathrm{d}}$ Methidathion \\
\hline Solubility in water & $39.8 \mathrm{~g} / \mathrm{L}$ & $40 \mathrm{mg} / \mathrm{L}$ & $0.39 \mathrm{mg} / \mathrm{L}$ & $221 \mathrm{mg} / \mathrm{L}$ \\
Octanol/water partition coefficient & 0.704 & 3.30 & 5.0 & 2.22 \\
Photolysis characteristics t1/2 (summer) & - & 4 days & 4.2 days & 8.2 days \\
Hydrolysis characteristics t1/2 at pH5 & 72 days & 156 days & 38 days & 37 days \\
\hline
\end{tabular}

$\left({ }^{\mathrm{a}} 18,{ }^{\mathrm{b}} 16,{ }^{\mathrm{c}} 17,{ }^{\mathrm{d}} 19\right)$

Table 3. Kinetic models of pesticides at $50{ }^{\circ} \mathrm{C}$ and $60^{\circ} \mathrm{C}$

\begin{tabular}{lcc}
\hline Pesticides & $50{ }^{\circ} \mathrm{C}$ & $60^{\circ} \mathrm{C}$ \\
\hline \multirow{2}{*}{ Dimethoate } & $y=16.635 \mathrm{e}^{-0.067 x}$ & $\mathrm{y}=1.4105 \mathrm{e}^{-0.11 x}$ \\
& $\mathrm{R}^{2}=0.975$ & $\mathrm{R}^{2}=0.949$ \\
Diazinon & $y=1.763 \mathrm{e}^{-0.078 x}$ & $\mathrm{y}=0.8564 \mathrm{e}^{-0.153 x}$ \\
& $\mathrm{R}^{2}=0.9506$ & $\mathrm{R}^{2}=0.9689$ \\
Chlorpyriphos & $y=1.2039 \mathrm{e}^{-0.044 x}$ & $\mathrm{y}=0.8424 \mathrm{e}^{-0.072 x}$ \\
& $\mathrm{R}^{2}=0.9395$ & $\mathrm{R}^{2}=0.9607$ \\
Methidathion & $y=1.1394 \mathrm{e}^{-0.035 x}$ & $\mathrm{y}=0.9539 \mathrm{e}^{-0.064 x}$ \\
& $\mathrm{R}^{2}=0.9344$ & $\mathrm{R}^{2}=0.9736$ \\
\hline
\end{tabular}

\section{Oven Drying}

When the temperature increased, degradation of pesticides raised (Table 1 ). Drying in the oven at $70{ }^{\circ} \mathrm{C}$ and $80{ }^{\circ} \mathrm{C}$ cause drastic reduction (above $90 \%$ ) in short time. Therefore those data were not convenient for kinetic evaluation.

During oven-drying, the pesticides followed the first order kinetic model. Table 3 summarizes the pesticide degradation rate constants and regression coefficients obtained. Half-lives of chlorpyrifos, diazinon, methidathion and dimethoate were respectively $15.75,8.89,19.8,10.35$ hours at $50^{\circ} \mathrm{C}$ and $9.63,4.53,10.83,6.3$ hours at $60^{\circ} \mathrm{C}$.

The activation energies of dimethoate, diazinon, chlorpyrifos and methidathion were calculated as 42.02, 42.18, 42.01 and $41.08 \mathrm{~J} / \mathrm{mol}$, respectively. There was no information related to activation energies of pesticides for grapes in the literature.

\section{CONCLUSION}

As a result, this study showed that the higher the temperature, the fastest the degradation of pesticides in drying processes of grapes. Physicalchemical characteristics of pesticides were not effective on pesticide residues during oven drying. Thermal degradation was the determinative mechanism for oven drying.

\section{ACKNOWLEDGEMENT}

This research was supported by the Scientific Research Projects Unit of Gaziosmanpasa University.

\section{REFERENCES}

1. Göktürk Baydar N, Akkurt M. 2001. Oil Content and Oil Quality Properties of Some Grape Seeds. Turk J Agric For, 25, 163-168.

2. Özden Ç. 2005. Kuru Üzüm (Raisins). T.C. Başbakanlık D1ş Ticaret Müsteşarlığı İhracatı Geliştirme Etüd Merkezi. 1-5.

3. Savant RH, Banerjee K, Utture SC, Patil SH, Dasgupta S, Ghaste MS, Adsule PG. 2010. Multiresidue Analysis of 50 Pesticides in Grape, Pomegranate, and Mango by Gas ChromatographyIon Trap Mass Spectrometry. J Agric Food Chem, 58, 1447-1454.

4. Turgut C, Örnek H, Cutright TJ. 2010. Pesticide residues in dried table grapes from the Aegean region of Turkey. Environ Monit Assess, 67, 143-149.

5. Cabras P, Garau VL, Pirisi FM, Cubeddu M, Cabitza F, Spanedda L. 1995. Fate of Some Insecticides from Vine to Wine. J Agric Food Chem, 43, 2613-2615.

6. Fang Y, Zhang A, Wang H, Li H, Zhang Z, Chen S, Luan L. 2010. Health risk assessment of trace elements in Chinese raisins produced in Xinjiang province. Food Control, 21, 732-739. 
7. Amvrazi E, Albanis T. 2008. Multiclass pesticide determination in olives and their processing factors in olive oil: Comparison of different olive oil extraction systems. I Agric Food Chem, 56, 5700-5709.

8. Amvrazi EG. 2010. Report "Fate of Pesticide Residues on Raw Agricultural Crops after Post harvest Storage and Food Processing to Edible Portions". Pesticides - Formulations, Effects, Fate. 28, 576-594.

9. González-Rodr guez RM, Rial-Otero R, CanchoGrande B, Gonzalez-Barreiro C, Simal Gándara J. 2011. A Review on the Fate of Pesticides during the Processes within the Food Production Chain. Crit Rev Food Sci Nutr, 51, 99-114.

10. Ke Keikotlhaile, BM, Spanoghe P. 2011. Pesticide Residues in Fruits and Vegetables. In: Stoytcheva M (ed) Pesticides - Formulations, Effects, Fate. Pesticides - Formulations, Effects, Fate Available via InTech. http://www.intechopen. com/books/pesticides- formulations-effects-fate/ pesticide-residues-in-fruits-andvegetables.

11. AOAC 1997. Official Methods of Analysis of AOAC International (16th. Pub), (930.15). Arlington, VA, USA.
12. Lehotay SJ, De-Kok A, Hiemstra M, Bodegraven P. 2005. Validation of a fast and easy method for the determination of residues from 229 pesticides in fruits and vegetables using gas and liquid chromatography and mass spectrometric detection. J AOAC Int, 88, 595-612.

13. JMPR 2009. JMPR Practices in Evaluation of Pesticide Residue Data. In: Submission and Evaluation of Pesticide Residue Data for the Estimation of Maximum Residue Levels in Food and Feed. FAO Plant Production and Protection Paper 197. FAO, Rome, p 68.

14. Cabras P, Angioni A. 2000. Pesticide Residues in Grapes, Wine, and Their Processing Products. J Agric Food Chem, 48, 967-973.

15. Katagi T. 2004. Photodegradation of pesticides on plant and soil surfaces. Rev Environ Contam Toxicol, 182, 181-189.

16. FAO 1988. Diazinon. FAO Specifications For Plant Protection Products

17. FAO 2004. Chlorpyrifos. FAO Specifications For Plant Protection Products

18. FAO 2012. Dimethoate. FAO Specifications For Plant Protection Products

19. Washburn AD. 2003. The Environmental Fate of Methidathion. http://www.cdpr.ca.gov/ docs/emon/pubs/fatememo/methidathion.pdf 